\title{
Phytoprotection
}

\section{Persistence of insecticidal activity of novel bio-encapsulated formulations of Bacillus thuringiensis var. kurstaki against Choristoneura rosaceana [Lepidoptera: Tortricidae] Persistance de l'activité insecticide de formulations bio-encapsulées du Bacillus thuringiensis var. kurstaki contre Choristoneura rosaceana [Lepidoptera : Tortricidae]}

\author{
J.-C. Côté, C. Vincent, K.-H. Son et S. H. Bok
}

Volume 82, numéro 2, 2001

URI : https://id.erudit.org/iderudit/706218ar

DOI : https://doi.org/10.7202/706218ar

Aller au sommaire du numéro

Éditeur(s)

Société de protection des plantes du Québec (SPPQ)l

ISSN

0031-9511 (imprimé)

1710-1603 (numérique)

Découvrir la revue

Citer cet article

Côté, J.-C., Vincent, C., Son, K.-H. \& Bok, S. H. (2001). Persistence of insecticidal activity of novel bio-encapsulated formulations of Bacillus thuringiensis var. kurstaki against Choristoneura rosaceana [Lepidoptera: Tortricidae]. Phytoprotection, 82(2), 73-82. https://doi.org/10.7202/706218ar
Résumé de l'article

Le DiPel ${ }^{\mathrm{TM}}$, une formulation commerciale du Bacillus thuringiensis var. kurstaki (Btk), et des formulations bio-encapsulées du Btk ont été pulvérisées dans un verger de pommiers. Pendant trois années consécutives, leur persistance a été évaluée en laboratoire sur des larves de tordeuse à bandes obliques (Choristoneura rosaceana). En 1995, le DiPel et la formulation bio-encapsulée ont causé une mortalité larvaire significativement plus grande que celle du témoin, au moins 1 jour et jusqu'à 27 jours après les traitements, respectivement. En 1996, bien que 6 mm de pluie soient tombés la journée des traitements, le DiPel et la formulation bio-encapsulée ont causé respectivement 21 et $33 \%$ de mortalité larvaire immédiatement après les traitements. Le DiPel a causé une mortalité significativement plus grande que celle du témoin pour une période de trois jours après les traitements alors que la formulation bio-encapsulée a causé une mortalité plus grande pendant 14 jours. En 1997, deux souches de Btk (HD-1 et BMP123) ont été pulvérisées à des concentrations

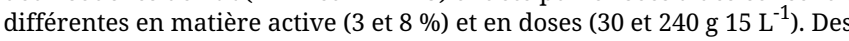
concentrations élevées en matière active et des doses élevées ont accru la persistance de l'activité insecticide des formulations de Btk. Parmi les facteurs météorologiques mesurés (précipitations, température et radiations solaires), les précipitations ont réduit la persistance de l'activité insecticide. Les radiations solaires peuvent également avoir contribué à moduler la persistance des formulations. 


\title{
Persistence of insecticidal activity of novel bio- encapsulated formulations of Bacillus thuringiensis var. kurstaki against Choristoneura rosaceana [Lepidoptera: Tortricidae]
}

\author{
Jean-Charles Côté ${ }^{1}$, Charles Vincent ${ }^{1}$, Kwang-Hee Son ${ }^{2}$, and \\ Song Hae Bok ${ }^{2}$
}

Received 2001-02-16; accepted 2001-08-10

PHYTOPROTECTION 82 : 73-82

$\mathrm{DiPel}^{\mathrm{TM}}$, a registered Bacillus thuringiensis var. kurstaki (Btk)-based formulation, and experimental bio-encapsulated Btk formulations were sprayed in an apple orchard. Their persistence was assessed in the laboratory against obliquebanded leafroller (Choristoneura rosaceana) larvae for three consecutive years. In 1995, DiPel and the bio-encapsulated formulation caused significantly higher larval mortality than the control at least 1 day, and up to 27 days after treatments, respectively. In 1996, although $6.4 \mathrm{~mm}$ of rain fell during the day of treatments, DiPel and the bio-encapsulated formulation caused respectively 21 and $33 \%$ larval mortality immediately after treatments. DiPel caused significantly higher mortality than the control for up to 3 days while the bio-encapsulated formulation caused significantly higher mortality for up to 14 days. In 1997, two Btk strains (HD-1 and BMP123) were sprayed at different concentrations in a.i. ( 3 and $8 \%$ ) and

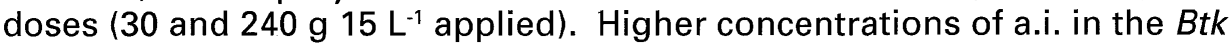
formulations and higher doses sprayed increased the persistence of the insecticidal activity. Among the meteorological factors that were measured (i.e. precipitations, temperature and solar radiations), precipitations reduced the persistence of the insecticidal activity. Solar radiations may have modulated the persistence of the formulations.

[Persistance de l'activité insecticide de formulations bio-encapsulées du Bacillus thuringiensis var. kurstaki contre Choristoneura rosaceana [Lepidoptera : Tortricidae]]

Le DiPel ${ }^{\mathrm{TM}}$, une formulation commerciale du Bacillus thuringiensis var. kurstaki (Btk), et des formulations bio-encapsulées du Btk ont été pulvérisées dans un verger de pommiers. Pendant trois années consécutives, leur persistance a été évaluée en laboratoire sur des larves de tordeuse à bandes obliques (Choristoneura rosaceana). En 1995, le DiPel et la formulation bio-encapsulée ont causé une mortalité larvaire significativement plus grande que celle du témoin, au moins 1 jour et jusqu'à 27 jours après les traitements, respectivement. En 1996, bien que $6 \mathrm{~mm}$ de pluie soient

1. Horticultural Research and Development Centre, Agriculture and Agri-Food Canada, 430 Gouin Blvd, Saint-Jean-sur-Richelieu (Quebec), Canada J3B 3E6; e-mail; cotejc@em.agr.ca

2. Korea Research Institute in Biosciences and Biotechnology, P.O. Box 115, Yu-Sung, Taejon 305-600, Korea 
tombés la journée des traitements, le DiPel et la formulation bio-encapsulée ont causé respectivement 21 et $33 \%$ de mortalité larvaire immédiatement après les traitements. Le DiPel a causé une mortalité significativement plus grande que celle du témoin pour une période de trois jours après les traitements alors que la formulation bio-encapsulée a causé une mortalité plus grande pendant 14 jours. En 1997, deux souches de Btk (HD-1 et BMP123) ont été pulvérisées à des concentrations différentes en matière

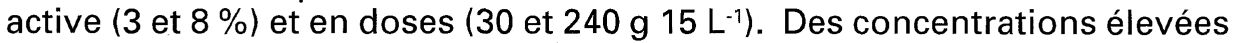
en matière active et des doses élevées ont accru la persistance de l'activité insecticide des formulations de Btk. Parmi les facteurs météorologiques mesurés (précipitations, température et radiations solaires), les précipitations ont réduit la persistance de l'activité insecticide. Les radiations solaires peuvent également avoir contribué à moduler la persistance des formulations.

\section{INTRODUCTION}

Formulation is a key component for the success of microbial pesticides. As defined by Burges and Jones (1998), a microbial pesticide "formulation comprises aids to preserving organisms, to delivering them to their targets, and once there, to improve their activities".

Several Bacillus thuringiensis var. kurstaki (Btk)-based commercial formulations are used as alternatives to chemical insecticides for the control of lepidopteran pests. They suffer, however, from short persistence caused by rain washing, lack of adherence on leaf surface and degradation of biologically active proteins by UV light (Frye et al. 1973; Pinnock et al. 1971; van Frankenhuyzen and Nystrom 1989). In field situations, sunlight, especially wavelengths ca. $300 \mathrm{~nm}$, is most destructive to Bacillus thuringiensis spores and protoxins (Jones and Burges 1998). Consequently, several applications must be done each season to achieve adequate crop protection. This limits the usefulness of Btk formulations that are commercially available.

To address the problem of short persistence, longer lasting Btk formulations have been developed. Encapsulation technology, a process whereby a chemical pesticide is coated with synthetic polymers, has been used initially to protect chemical pesticides from degradation in the environment or, alternatively, to provide controlled release of the active ingredient (Raun and Jackson 1966). Similar technologies have been developed for microbial pesticides. Btk has been encapsulated with clay (Ahmed et al. 1973; Raun and Jackson 1966), UV-absorbing compounds (Hostetter et al. 1975), chemical polymer matrices such as polyvinylpyrrolidone and polyvinylalcohol (Baker et al. 1987), and in a starch matrix without the use of chemical cross-linking agents (Dunkle and Shasha 1988, 1989). The latter, referred to as bio-encapsulation, uses an abundant source of natural biopolymer as coating materials. It uses mild conditions during the bio-encapsulation process so that up to $70 \%$ of the insecticidal activity is retained after a 2-wk period in simulated rain in a greenhouse (McGuire and Shasha 1990).

The bio-encapsulation process of Btk and other microorganisms has been further modified by Bok et al. (1993). This chemical-free technique uses a series of inexpensive biopolymers such as potato starch combined with rice flour and rye, barley and soybean powders. These polymers act as stickers to provide improved adhesiveness to the plant leaves. By entrapping the active ingredient, they could presumably retain its entomocidal activity through better protection against dessication, sunlight, heat and the damaging effects of UVlight (Bok et al. 1993).

The obliquebanded leafroller, Choristoneura rosaceana Harris [Lepidoptera : Tortricidae], is a polyphagous insect that 
became resistant to several synthetic insecticides in some apple growing areas of North America, including New York state (Reissig 1978; Reissig et al. 1986) and Quebec (Carrière et al. 1994; Smirle et al. 1998). Alternatives to synthetic insecticides with different modes of action are needed to alleviate or delay resistance. Btk formulations would be particularly useful in this context. In Nova Scotia apple orchards, Hardman and Gaul (1990) found that obliquebanded leafroller fruit injury was $0.25 \%$ following DiPel ${ }^{\mathrm{TM}}$ application $(3.48 \%$ fruit injury in the control, with no significant difference). Commercial formulations of Btk have been assayed in raspberry fields. The half-life of DiPel WP and Foray $48 \mathrm{~B}$ ranged from 2.45 to $6.68 \mathrm{~d}$, depending on application rate or spray volume (Li and Fitzpatrick 1996). Higher residual activity was obtained at higher application rates and at lower spray volumes. Btk formulations should ensure adequate larval control, provided that the formulations would remain active for a sustained period on the foliage.

Little has been published on the persistence of long lasting formulations in field situations, most notably in agricultural tree-fruit situations. In the present study, bio-encapsulated formulations of Btk were assessed for their residual activity in an apple orchard located in Frelighsburg (Quebec) in summers 1995, 1996 and 1997, using bio-assays against obliquebanded leafroller larvae.

\section{MATERIALS AND METHODS}

\section{Bacterial strains}

Btk strain HD-1 was isolated from DiPel, a formulation developed by Abbott Laboratories, Chemicals and Agricultural Products Division, North Chicago, Illinois, U.S.A. Btk strain BMP-123 was obtained from T. Couch, Becker Microbials, Plantation, Florida, U.S.A.

\section{Bio-encapsulation of Bacillus thuringiensis}

The bio-encapsulated $B$. thuringiensis was prepared as described in Bok et al. (1993). In summary, a culture of Btk strain HD-1 or strain BMP-123 was grown in SYG medium (2\% soytone, $1 \%$ glucose, $0.2 \%$ yeast extract, $0.1 \%$ $\mathrm{K}_{2} \mathrm{HPO}_{4}, 0.1 \% \mathrm{KH}_{2} \mathrm{PO}_{4}, 0.05 \% \mathrm{MgSO}_{4^{-}}$ $7 \mathrm{H}_{2} \mathrm{O}, 0.02 \% \mathrm{MnCl}_{2}, 0.02 \% \mathrm{ZnSO}_{4}-7 \mathrm{H}_{2} \mathrm{O}$, $0.02 \% \mathrm{FeSO}_{4}-7 \mathrm{H}_{2} \mathrm{O}, \mathrm{pH} 7.0$ ) at $30^{\circ} \mathrm{C}$, for $5 \mathrm{~d}$ until sporulation. The sporulated culture was centrifuged at $10000 \times \mathrm{g}$ for $30 \mathrm{~min}$ at $4^{\circ} \mathrm{C}$. A biogel matrix was prepared by mixing the following series of powders and salts $(100 \mathrm{~g}$ rice powder, $100 \mathrm{~g}$ soybean powder, $10 \mathrm{~g}$ cotton seed powder, $2 \mathrm{~g}$ glucose, $1 \mathrm{~g}$ $\mathrm{CaCO}_{3}, 1 \mathrm{~g}$ yeast extract, $20 \mathrm{~g}$ soil, 50 $\mathrm{mg} \mathrm{FeSO}_{4}-7 \mathrm{H}_{2} \mathrm{O}$ and $10 \mathrm{mg} \mathrm{MnCl}-4 \mathrm{H}_{2} \mathrm{O}$ ). The mixture was boiled for $1 \mathrm{~h}$ with vigorous stirring and autoclaved at $121^{\circ} \mathrm{C}$ for $30 \mathrm{~min}$. After cooling, $2 \times 10^{11}$ spores were added and thoroughly mixed. The gel was spread on a plate and dried at room temperature for $2 \mathrm{~d}$. The dried complex was ground to a fine powder of 75-100 $\mu \mathrm{m}$ in diam containing $5 \times 10^{8}$ spores $\mathrm{g}^{-1}$.

\section{Bacillus thuringiensis formulations and evaluation of B.I.U.}

DiPel WP, a Btk strain HD-1-based wettable powder, was used as a standard. The commercial label indicated that the formulation contained 16 billion International Units (B.I.U.) per kg. The number of B.I.U. in DiPel and in the bioencapsulated formulations of Btk HD-1 and Btk BMP123 were determined by standardized bioassays on Trichoplusia ni (Hbn.) [Lepidoptera : Noctuidae] larvae as described by Dulmage et al. (1971). In 1995, laboratory bioassays on T. ni determined that the bio-encapsulated product had, on an equal weight basis, ca. $12.5 \%$ the number of B.I.U. contained in DiPel. Instead of equal amount of formulations we decided to spray equivalent amount of a.i., as measured in B.I.U., of DiPel and bioencapsulated $B$. thuringiensis. Consequently, on a weight to weight basis, eight times more bio-encapsulated $B$. thuringiensis were sprayed in the field in 1995 compared to DiPel, so that equivalent number of B.I.U. per applied dose were used (Table 1).

In 1996, laboratory bioassays determined that the bio-encapsulated Bt formulation contained $10 \%$ the number of B.I.U. of DiPel on an equal weight basis. 
Consequently, on a weight to weight basis, 10 times more bio-encapsulated Bacillus thuringiensis product than DiPel were sprayed to ensure that equivalent amount of biologically-active material were used (Table 1).

In 1997, laboratory bio-assays determined that, on an equal weight basis, the bio-encapsulated $\mathrm{Bt}$ formulations $\mathrm{H} 3$ and B3 contained $12.5 \%$ the amount of B.I.U. of DiPel, and formulations $\mathrm{H} 8$ and B8, 33\% (Table 1).

\section{Field trials}

All trials were done at the Agriculture and Agri-Food Canada Experimental Farm located at Frelighsburg $\left(45^{\circ} 03^{\prime} \mathrm{N}\right.$, $75^{\circ} 50^{\prime}$ W), Quebec, in an apple orchard composed of cultivar "Liberty". The field layout consisted of several experimental units, each comprising five contiguous trees in a row per treatment, with a row of trees acting as buffer between each treated rows. The field layouts were similar in 1995, 1996 and 1997. The treatments were applied directly on apple trees with a handgun until runoff on 16 August 1995, 9 July 1996 and 4 September 1997.

Meteorological data were collected by an automatic weather station located on the farm ca. $600 \mathrm{~m}$ from the plots. Solar radiation $\left(\mathrm{MJ} \mathrm{m}^{-2}\right)$ was measured with a pyranometer (LI-200SZ) (Li-Cor, Lincoln, Nebraska, U.S.A.) that had a sensor with a defined response from 385 to $1110 \mathrm{~nm}$.

\section{Laboratory bioassays of Btk persistence in the field}

To assess the residual activity of the formulations, 15 apple leaves were randomly collected on trees of each treatment at different dates after treatment (see Tables 2, 3 and 4 for collecting schedule). They were immediately brought to the laboratory in a refrigerator where they were kept for a few hours until the bioassays. Leaf disks of $15 \mathrm{~mm}$ diam were cut with a metal auger. Third instar larvae were individually starved for $24 \mathrm{~h}$ before the biossays and individually offered one leaf disk (treated or control) for $24 \mathrm{~h}$. The

Table 1. Summary of dates of treatments, treatments applied, a.i. used, number of billion International units (B.I.U.) $\mathrm{kg}^{-1}$, applied dose (g $\left.15 \mathrm{~L}^{-1}\right)$ and B.I.U. per applied dose

\begin{tabular}{|c|c|c|c|c|c|}
\hline $\begin{array}{l}\text { Dates of treatments } \\
\text { (no. of larvae testec } \\
\text { per treatment) }\end{array}$ & $\begin{array}{l}\text { d } \\
\text { Treatments } \\
\end{array}$ & $\begin{array}{c}\text { Active } \\
\text { ingredients }\end{array}$ & B.I.U. $\mathrm{kg}^{-1}$ & $\begin{array}{l}\text { Applied dose } \\
\text { (g } 15 \mathrm{~L}^{-1} \\
\text { applied) }\end{array}$ & $\begin{array}{l}\text { B.I.U./ } \\
\text { applied } \\
\text { dose }\end{array}$ \\
\hline $\begin{array}{l}16 \text { August } 1995 \\
(\mathrm{n}=30)\end{array}$ & $\begin{array}{l}\text { Control } \\
\text { DiPel WP } \\
\text { H3-240 }\end{array}$ & $\begin{array}{l}\text { Water } \\
\text { HD-1 DiPel } \\
\text { HD-1 }\end{array}$ & $\begin{array}{r}16 \\
2\end{array}$ & $\begin{array}{r}30 \\
240\end{array}$ & $\begin{array}{l}0.48 \\
0.48\end{array}$ \\
\hline $\begin{array}{l}9 \text { July } 1996 \\
(n=40)\end{array}$ & $\begin{array}{l}\text { Control } \\
\text { DiPel WP } \\
\mathrm{H} 2-300\end{array}$ & $\begin{array}{l}\text { Water } \\
\text { HD-1 DiPel } \\
\text { HD-1 }\end{array}$ & $\begin{array}{r}16 \\
1.6\end{array}$ & $\begin{array}{r}30 \\
300\end{array}$ & $\begin{array}{l}0.48 \\
0.48\end{array}$ \\
\hline $\begin{array}{l}4 \text { September } 1997 \\
(n=40)\end{array}$ & $\begin{array}{l}\text { Control } \\
\text { DiPel WP } \\
\text { H3-30 } \\
\text { H8-30 } \\
\text { B3-30 } \\
\text { B8-30 } \\
\text { H3-240 } \\
\text { B3-240 } \\
\text { DiPel WP } \\
\text { H8-240 } \\
\text { B8-240 }\end{array}$ & $\begin{array}{l}\text { Water } \\
\text { HD-1 DiPel } \\
\text { HD-1 } \\
\text { HD-1 } \\
\text { BMP123 } \\
\text { BMP123 } \\
\text { HD-1 } \\
\text { BMP123 } \\
\text { HD-1 DiPel } \\
\text { HD-1 } \\
\text { BMP123 }\end{array}$ & $\begin{array}{r}16 \\
2 \\
5.3 \\
2 \\
5.3 \\
2 \\
2 \\
16 \\
5.3 \\
5.3\end{array}$ & $\begin{array}{r}30 \\
30 \\
30 \\
30 \\
30 \\
240 \\
240 \\
240 \\
240 \\
240\end{array}$ & $\begin{array}{l}0.48 \\
0.06 \\
0.16 \\
0.06 \\
0.16 \\
0.48 \\
0.48 \\
3.84 \\
1.28 \\
1.28\end{array}$ \\
\hline
\end{tabular}

a Tween ${ }^{\circledR 2} 20$ was added at a $0.1 \%$ level to each treatment, including the controls.

b Acronym for the bio-encapsulated formulation : the first letter, $\mathrm{H}$ or $\mathrm{B}$, stands for Bacillus thuringiensis var. kurstaki strains HD-1 and BMP123, respectively; the first number, 2, 3 or 8 , stands for the percent of Bacillus thuringiensis a.i. in the formulation; the second number, 30,240 or 300 , stands for the amount $(\mathrm{g})$ of bio-encapsulated products suspended in $15 \mathrm{~L}$ of water and applied to trees. 
Table 2. Percent larval mortality of obliquebanded leafroller six days following ingestion of Btk treated leaf disks taken from leaves collected on apple trees sprayed on 16 August $1995^{a}$

\begin{tabular}{cccc}
\hline & \multicolumn{3}{c}{ Larval mortality $(\%)^{\mathrm{b}}$} \\
\cline { 2 - 4 } $\begin{array}{c}\text { Days after } \\
\text { treatment }\end{array}$ & Control & DiPel & H3-240 \\
\hline 0 & 7 & $87^{*}$ & $72^{*}$ \\
1 & 7 & $47^{*}$ & $67^{*}$ \\
6 & 7 & 10 & $53^{*}$ \\
13 & 0 & 0 & $30^{*}$ \\
20 & 7 & 11 & $30^{*}$ \\
27 & 3 & 7 & $14^{*}$ \\
\hline
\end{tabular}

a see Table 1 for description of treatments.

b $\mathrm{n}=30$ larvae per treatment.

* significantly different from the control $(P$ $=0.05$, test for comparisons of proportions, Zar 1996).
Table 3. Percent larval mortality of obliquebanded leafroller six days following ingestion of Btk treated leaf disks taken from leaves collected on apple trees sprayed on 9 July $1996^{\mathrm{a}}$

\begin{tabular}{cccc}
\hline & \multicolumn{3}{c}{ Larval mortality $(\%)^{\mathrm{b}}$} \\
$\begin{array}{c}\text { Days after } \\
\text { treatment }\end{array}$ & Control & DiPel & $\mathrm{H} 3-240$ \\
\hline 0 & 0 & $21^{*}$ & $33^{*}$ \\
1 & 10 & 5 & 18 \\
3 & 0 & $8^{*}$ & $15^{*}$ \\
7 & 3 & 3 & 10 \\
10 & 0 & 0 & $8^{*}$ \\
14 & 0 & 3 & $8^{*}$ \\
\hline a see Table 1 for description of treatments. \\
b $\mathrm{n}=40$ larvae per treatment. \\
* significantly different from the control $(P$ \\
$=0.05$, test for comparisons of proportions, \\
Zar 1996).
\end{tabular}

Table 4. Percent larval mortality of obliquebanded leafroller six days following ingestion of Btk treated leaf disks taken from leaves collected on apple trees sprayed on 4 September $1997^{\text {a }}$

\begin{tabular}{|c|c|c|c|c|c|c|c|c|c|c|c|}
\hline \multirow{3}{*}{$\begin{array}{l}\text { Days } \\
\text { after } \\
\text { treat- } \\
\text { ment }\end{array}$} & & & \multicolumn{9}{|c|}{ Larval mortality $(\%)^{b}$} \\
\hline & & & \multicolumn{4}{|c|}{ Group $A^{c}$} & \multicolumn{2}{|c|}{ Group B } & \multicolumn{3}{|c|}{ Group C } \\
\hline & Contro & DiPel 30d & $\mathrm{H} 3-30$ & $\mathrm{H} 8-30$ & B3-30 & $\mathrm{B} 8-30$ & $\mathrm{H} 3-240$ & B3-240 & DiPel 240 & $\mathrm{H} 8-240$ & B8-240 \\
\hline 0 & 2.6 & $25.6 \mathrm{a}$ & $12.8 a, b$ & $5.1 \mathrm{~b}$ & $5 b$ & $15.8 \mathrm{a}$ & $33.3 \mathrm{a}$ & $20 a$ & $67.5 a, b$ & $46.2 a, b, c$ & $53.8 a, b$ \\
\hline 1 & 0 & 5 & 2.5 & 2.5 & 0 & 0 & $17.5 a, b$ & $15.8 a, b$ & $71.8 a, b$ & $35.9 a, b, c$ & $25 a, b, c$ \\
\hline 5 & 0 & $7.5 \mathrm{a}$ & $0 \mathrm{~b}$ & $0 \mathrm{~b}$ & 2.6 & $0 \mathrm{~b}$ & $10 \mathrm{a}$ & $7.5 \mathrm{a}$ & $39.5 a, b$ & $20 a, b, c$ & $20 a, b, c$ \\
\hline 12 & 0 & 2.5 & $10 a$ & 2.5 & 0 & 5.3 & 0 & 0 & $15.4 a, b$ & $5 \mathrm{c}$ & $12.5 \mathrm{a}, \mathrm{b}$ \\
\hline 19 & 0 & 2.5 & 0 & 2.5 & 5 & 5.1 & 0 & 5 & 5 & 0 & 0 \\
\hline 26 & 2.5 & 5 & 2.6 & 0 & 0 & 0 & 5 & 2.5 & 0 & 2.5 & 10 \\
\hline
\end{tabular}

a see Table 1 for description of treatments.

b $n=40$ larvae per treatment.

c Group A: treatments applied on trees at $30 \mathrm{~g} \mathrm{~L}^{-1}$ with bio-encapsulated formulations containing 3 or $8 \%$ a.i.; group B: treatments applied on trees at $240 \mathrm{~g} \mathrm{~L}^{-1}$ with bio-encapsulated formulations containing 3\% a.i.; group C: treatments (i.e. the commercial standard DiPel or bio-encapsulated formulations containing $8 \%$ a.i.) applied on trees at $240 \mathrm{~g} \mathrm{~L}^{-1}$.

d Treatment comparisons and significance $(P=0.05$, test for comparisons of proportions, Zar 1996): percent followed by an "a" are significantly different from the control; within group $A, B$, and $C$, percent followed by a " $b$ " are significantly different from that of DiPel-30; and within group $\mathrm{C}$, percent followed by a " $\mathrm{c}$ " are significantly different from DiPel-240.

larvae were then transferred individually into a plastic Solo® cup (Solo Cup Co., Urbana, Illinois, U.S.A.) containing a pinto bean-based artificial diet (modified from Shorey and Hale 1965). The cups were kept at $24^{\circ} \mathrm{C}$ and $16 \mathrm{~L}: 8 \mathrm{D}$ photoperiod. Larval mortality was recorded daily for $6 \mathrm{~d}$.

\section{Statistical analysis}

For each date after the treatment, statistical differences between larval mortality in treatments and the control were detected by using the test for comparing proportions with $P=0.05$ (Zar 1996, box 23.23). In 1995 and 1996, percent of larval mortality in the treatments was 
compared to that of the control. In 1997 , recorded percent of larval mortality were compared respectively with 1) the control, 2) the commercial standard at the recommended dose (i.e. DiPel 30) and 3 ) the commercial standard at a high dose (i.e. DiPel 240).

\section{RESULTS}

In preliminary trials and bioassays conducted in July 1995, larval mortality caused by DiPel immediately after treatment was five-fold higher than mortality caused by the bio-encapsulated $B$. thuringiensis when equal amount of formulated products were used (data not shown). Because of the large total amount of ingredients used for bioencapsulation, the relative amount of $B$. thuringiensis, the a.i. measured in B.I.U. $\mathrm{kg}^{-1}$, was lower in the bio-encapsulated product than in DiPel (Table 1). A second series of treatments was conducted on 16 August 1995 with equivalent amount of B.I.U. per applied dose. Larval mortality in the control varied from 0 to $7 \%$ (Table 2). Immediately after treatment, DiPel caused $87 \%$ larval mortality. Twenty-four $h$ later, larval mortality was down to $47 \%$ and subsequent mortality was not significantly different from that of the control, ranging from $0-11 \%$. The bio-encapsulated $B$. thuringiensis exerted control comparable to DiPel for the first $24 \mathrm{~h}$. Killing efficiency was, however, significantly different from the control for $d$ $6,13,20$ and 27 after treatment. Maximum temperatures for the period comprised between 16 August and 12 September 1995 slowly decreased from $c a$. 30 to $15^{\circ} \mathrm{C}$ (Table 5). Following spraying, slight precipitations of 5, 5.4 and 11 $\mathrm{mm}$ of rain were recorded on d 13, 15 and 22 , respectively. The cumulative solar radiation at $d 1,6,13,20$ and 27 after treatment was $47.2,156.9,278.5$, 402.7 and $516.2 \mathrm{MJ} \mathrm{m}^{-2}$, respectively.

In 1996, larval mortality in the control ranged from $0-10 \%$ throughout the course of the experiment (Table 3). DiPel caused a significantly higher larval mortality than the control immediately and $3 \mathrm{~d}$ after treatment. The bio-encap- sulated Btk formulation $\mathrm{H} 2-300$ gave a significantly higher percent of larval mortality than the control at $0,3,10$ and $14 \mathrm{~d}$ after treatment. Maximum temperatures between 9 July and 30 July 1996 ranged in the mid '20s (Table 5). Several d with precipitation were recorded during the period under study, i.e. $6.4,8,3.2,26,24,22.8$ and $17.8 \mathrm{~mm}$ of rain registered $0,4,5,6,7,10$ and $11 \mathrm{~d}$ respectively following spraying. The cumulative solar radiation at $d 1,3$, 7,10 and 14 after treatment was 37.7 , $87.2,133.8,185.1$ and $259.2 \mathrm{MJ} \mathrm{m}^{-2}$, respectively.

In 1997, a more throrough trial was conducted. A first series of treatments was done on 12 August (data not shown). The data were discarded because heavy rain fell after the treatment. A second treatment was applied on 4 September 1997 (Table 4). Two Btk strains were sprayed, HD-1 and BMP123. Both strains were bio-encapsulated at different concentrations of B.I.U. $\mathrm{kg}^{-1}$ and applied in the field at different doses (Table 1). Hence, samples with equivalent amount of a.i. but different amount of final formulations, as well as samples with equal amount of total material but different amount of a.i., were sprayed to study the effect on larval mortality of 1) the concentration in a.i., and 2) the amount of total product used. Low $(\leq 2.6 \%)$ larval mortality was recorded in the control throughout the experiment (Table 4). Mortality caused by $\mathrm{DiPel} 30$ was $25.6 \%$ after treatment and subsequently $\leq 7.5 \%$. DiPel 240 caused ca. $70 \%$ mortality the first $24 \mathrm{~h}$ following treatment, and later mortality was significantly different from that of the control up to $12 \mathrm{~d}$ after treatment. All bio-encapsulated Btk formulations of group A (i.e. H3-30, B3-30, H8-30 and B8-30) caused $\leq 16 \%$ larval mortality immediately after treatment. Later mortality was not significantly different from that of the control, except for H330 at $d 12$ where $10 \%$ larval mortality was recorded.

Bio-encapsulated Btk formulations containing 3 or $8 \%$ a.i., applied at a rate

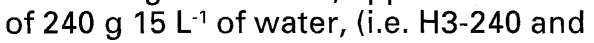
B3-240 in Group B; H8-240 and B8-240 in Group $C$ ) caused significantly more 
Table 5. Meteorological conditions that prevailed after treatments of apple trees with Btk formulations, in Frelighsburgh, Quebec, Canada. Dates of treatments appear between parentheses beside the year

\begin{tabular}{|c|c|c|c|c|c|c|c|c|c|c|c|c|}
\hline \multirow[b]{2}{*}{$\begin{array}{l}\text { Day } \\
\text { after } \\
\text { treatmen }\end{array}$} & \multicolumn{4}{|c|}{1995 (16 August) } & \multicolumn{4}{|c|}{1996 (9 July) } & \multicolumn{4}{|c|}{1997 (4 September) } \\
\hline & $\begin{array}{l}\text { Max. } \\
\text { ts }\left({ }^{\circ} \mathrm{C}\right)\end{array}$ & $\begin{array}{l}\text { Min. } \\
\left({ }^{\circ} \mathrm{C}\right)\end{array}$ & $\begin{array}{c}\text { Precipi- } \\
\text { tations } \\
\text { (mm) }\end{array}$ & $\begin{array}{l}\text { Solar } \\
\text { radiation } \\
\left(\mathrm{MJ} \mathrm{m}^{-2}\right)\end{array}$ & $\begin{array}{l}\text { Max. } \\
\left({ }^{\circ} \mathrm{C}\right)\end{array}$ & $\begin{array}{l}\text { Min. } \\
\left({ }^{\circ} \mathrm{C}\right)\end{array}$ & $\begin{array}{c}\text { Precipi- } \\
\text { tations } \\
(\mathrm{mm})\end{array}$ & $\begin{array}{c}\text { Solar } \\
\text { radiation } \\
\left(\mathrm{MJ} \mathrm{m}^{-2}\right)\end{array}$ & $\begin{array}{l}\text { Max. } \\
\left({ }^{\circ} \mathrm{C}\right)\end{array}$ & $\begin{array}{l}\text { Min. } \\
\left({ }^{\circ} \mathrm{C}\right)\end{array}$ & $\begin{array}{l}\text { Precipi- } \\
\text { tations } \\
(\mathrm{mm})\end{array}$ & $\begin{array}{l}\text { Solar } \\
\text { radiation } \\
\left\langle\mathrm{MJ} \mathrm{m}^{-2} \text { ) }\right.\end{array}$ \\
\hline 0 & 28.3 & 18.0 & 0 & 24.5 & 25.0 & 13.3 & 6.4 & 21.7 & 14.5 & 6.7 & 0 & 11.0 \\
\hline 1 & 30.2 & 15.7 & 0 & 22.7 & 19.4 & 13.8 & 1 & 16.0 & 21.6 & 8.0 & 0 & 20.7 \\
\hline 2 & 26.9 & 15.6 & 0 & 23.7 & 24.6 & 12.4 & 0 & 27.3 & 18.9 & 14.4 & 0 & 6.9 \\
\hline 3 & 26.5 & 14.4 & 0 & 24.5 & 26.5 & 14.4 & 0 & 22.2 & 17.6 & 9.6 & 0 & 3.3 \\
\hline 4 & 29.4 & 17.3 & 0 & 24.2 & 21.8 & 17.4 & 8 & 5.7 & 21.2 & 5.7 & 0 & 18.2 \\
\hline 5 & 29.1 & 19.1 & 0 & 24.2 & 27.0 & 16.8 & 3.2 & 14.5 & 23.4 & 8.3 & 1.2 & 17.2 \\
\hline 6 & 19.7 & 14.5 & 0 & 13.1 & 25.3 & 19.5 & 26 & 7.8 & 22.6 & 12.5 & 0 & 15.0 \\
\hline 7 & 21.2 & 11.1 & 0 & 16.9 & 25.5 & 17.4 & 24 & 18.6 & 22.5 & 15.9 & 0 & 9.7 \\
\hline 8 & 20.7 & 11.2 & 0 & 10.3 & 25.8 & 17.3 & 0 & 21.0 & 23.8 & 14.6 & 2.8 & 11.0 \\
\hline 9 & 20.3 & 9.9 & 0 & 16.8 & 28.0 & 16.0 & 0 & 24.0 & 21.6 & 13.5 & 0 & 13.4 \\
\hline 10 & 21.2 & 8.7 & 0 & 15.4 & 24.8 & 14.9 & 22.8 & 6.3 & 22.8 & 14.0 & 1.4 & 8.9 \\
\hline 11 & 21.7 & 7.2 & 0 & 19.1 & 15.6 & 12.1 & 17.8 & 5.6 & 22.3 & 13.0 & 0 & 11.5 \\
\hline 12 & 24.3 & 4.1 & 0 & 24.3 & 23.0 & 12.7 & 1 & 25.2 & 17.1 & 7.8 & 0 & 12.3 \\
\hline 13 & 24.7 & 12.2 & 5 & 18.8 & 26.6 & 10.6 & 0 & 27.0 & 21.4 & 5.4 & 4.6 & 16.3 \\
\hline 14 & 22.2 & 8.4 & 0 & 23.2 & 26.9 & 13.5 & 3.7 & 16.3 & 21.8 & 12.9 & 0 & 15.8 \\
\hline 15 & 21.0 & 11.9 & 5.4 & 7.4 & 27.9 & 16.6 & 1.1 & 22.3 & 23.4 & 11.8 & 0 & 11.6 \\
\hline 16 & 20.5 & 11.8 & 0 & 15.0 & 24.9 & 19.2 & 2.2 & 11.8 & 17.9 & 7.4 & 26.2 & 1.5 \\
\hline 17 & 20.4 & 7.7 & 0 & 19.9 & 25.3 & 16.7 & 2 & 18.1 & 10.4 & 2.3 & 1 & 9.3 \\
\hline 18 & 22.2 & 5.4 & 0 & 20.4 & 22.2 & 14.5 & 0 & 17.6 & 17.4 & 1.7 & 0 & 15.2 \\
\hline 19 & 24.7 & 11.1 & 0 & 21.1 & 23.0 & 11.2 & 0 & 24.1 & 13.6 & 1.9 & 8.6 & 2.9 \\
\hline 20 & 25.9 & 11.9 & 0 & 17.2 & 26.3 & 9.7 & 0 & 21.4 & 9.9 & -0.6 & 0 & 11.8 \\
\hline 21 & 21.2 & 7.4 & 0 & 23.2 & 23.4 & 17.5 & 0 & 10.6 & 16.6 & 5.0 & 0 & 13.1 \\
\hline 22 & 24.9 & 6.7 & 11 & 6.4 & $-a$ & - & - & - & 11.3 & 7.0 & 2.8 & 1.7 \\
\hline 23 & 16.4 & 2.9 & 0 & 22.2 & - & - & - & - & 16.0 & 1.2 & 0 & 16.0 \\
\hline 24 & 16.4 & 6.6 & 2 & 6.1 & - & - & - & - & 20.2 & 7.8 & 1.2 & 16.1 \\
\hline 25 & 14.2 & 3.5 & 0 & 16.5 & - & - & - & - & 14.8 & 11.1 & 26.4 & 2.6 \\
\hline 26 & 19.6 & 0.7 & 0 & 19.2 & - & - & - & - & 15.5 & 6.9 & 5.9 & 4.6 \\
\hline 27 & 24.1 & 11.1 & 0 & 19.9 & - & - & - & - & - & - & - & - \\
\hline
\end{tabular}

a Data not presented because the experiment was terminated.

mortality than the control up to $5 \mathrm{~d}$ after treatment except for formulation B8240 , where mortality was significantly greater than the control up to $12 \mathrm{~d}$ after treatment.

Mortalities recorded with all bio-encapsulated formulations and with DiPel 240 (Groups A, B and C) were compared to the ones caused by DiPel 30 . Bio-encapsulated formulations $\mathrm{H} 3-30$ and $\mathrm{B} 3-30$, and formulations $\mathrm{H} 8-30$ and B8-30 (Group A), contained respectively $1 / 8$ and $1 / 3$ the amount of a.i. found in DiPel 30 (Table 1). All four experimental formulations caused comparable or less larval mortality than DiPel 30. Bio-encapsulated formulations H3-240 and B3-240 (Group B), and formulations H8-240 and B8-240 (Group C), contained respectively one-fold and $22 / 3$-fold the amount of a.i. found in DiPel 30. Bioencapsulated formulations $\mathrm{H} 3-240$ and B3-240 caused significantly more mortality than DiPel $30,24 \mathrm{~h}$ after treatments whereas DiPel 240, H8-240 and B8-240 caused significantly more larval mortality than DiPel 30, at least $5 \mathrm{~d}$ after treatment and up to $12 \mathrm{~d}$ after treatment for DiPel 240 and B8-240.

Mortality recorded with $\mathrm{H} 8-240$ and B8-240 (Group C) was compared to that caused by DiPel 240. Both bio-encapsulated formulations contained $1 / 3$ the amount of a.i. found in $240 \mathrm{~g}$ of the commercial formulation, Dipel 240. DiPel 240 caused significantly higher mortalities than both bio-encapsulated formulations up to $5 \mathrm{~d}$ after treatment. 
Maximum temperatures for the period comprised between 4 and 30 September varied from 9.9 to $23.8^{\circ} \mathrm{C}$ (Table 5). Minimum temperatures varied from -0.6 to $15.9^{\circ} \mathrm{C}$. Two d with major precipitations of 26.2 and $26.4 \mathrm{~mm}$ of rain were recorded respectively 16 and $25 \mathrm{~d}$ after treatment. The cumulative solar radiation at $d 1,5,12,19$ and 26 after treatment was 31.7, 77.3, 159.1, 231.7 and $297.6 \mathrm{MJ} \mathrm{m}^{-2}$, respectively.

\section{DISCUSSION}

A variety of factors may limit the efficacy of these $B$. thuringiensis var. kurstaki formulations, short persistence being a key one. Longer lasting formulations would offer several advantages over currently registered Btk formulations. Because of the increased persistence of the activity on the foliage, less spraying would be required, thus reducing costs related to product and labor. The sustained activity of longer lasting Btk formulations could allow a greater flexibility in interpreting an optimal window of application. This feature can be useful, as in the case of the obliquebanded leafroller, an insect pest of apple orchards, where oviposition can span up to one month. Although obliquebanded leafroller larvae may be differentially sensitive to Btk (Li et al. 1995) and although eggs, pupae and adults will usually escape exposure (Rigby 1991), long-lasting residual activity may increase the likelihood that vulnerable stages may ingest the toxins.

Several abiotic factors (e.g. UV light, heat, rain, etc.) may affect the persistence of Btk formulations and, in field situations, the effect of these factors may be simultaneous and confounding (Jones and Burges 1998). Our results suggest that precipitation was a key factor in the non-persistence of the insecticidal activity. Under meteorological conditions with low rainfall, as exemplified in summer 1995, the bioencapsulated Bacillus thuringiensis lasted longer in the apple orchard than DiPel. In 1996, however, rain on the d of spraying (Table 5) appears to have reduced the persistence, and hence the activity, of both DiPel and the experi- mental Btkformulations (Table 3). Low mortality was recorded $24 \mathrm{~h}$ after spraying. In 1997, no rain fell during the first $4 \mathrm{~d}$ after treatment and low precipitation ( $<5 \mathrm{~mm}$ per d) fell occasionally during the next $11 \mathrm{~d}$.

Solar radiation that prevailed during the course of our field trials varied from $\mathrm{yr}$ to $\mathrm{yr}$. For example, in the first $6 \mathrm{~d}$ after treatment, 156.9, 115,2 and 92.3 MJ $\mathrm{m}^{-2}$ were measured in 1995, 1996 and 1997, respectively. Likewise, in the first $14 \mathrm{~d}$ after treatments, 301.7, 259.2 and $191.2 \mathrm{MJ} \mathrm{m}^{-2}$ were measured in 1995, 1996 and 1997, respectively. Solar radiation may have played a role in modulating the persistence of the Btk formulations in the field.

In contrast to the precipitation that often was negligible most of the time during the course of the trials but sporadically occured in large quantities in some d (e.g. d 6, 7, 10 and 11 in 1996), solar radiation accumulated steadily every d. Few days had $<10 \mathrm{MJ} \mathrm{m}^{-2}$ of radiation, respectively 3,3 and $10 \mathrm{~d}$ in 1995, 1996 and 1997.

In Quebec, meteorological conditions (e.g. rain, temperature and solar radiation) are often unpredictable and very variable throughout the season (G. Bourgeois, personal communication). These constitute very conservative conditions for field trials of pesticide formulations.

Among the manageable factors, concentration of a.i. in the formulation, total amount of formulation sprayed and identity of the bacterial strain used may influence the outcome of the trials but they must comply to registration and economic contingencies.

The concentration of a.i. in the formulations and the amount of total formulated powder sprayed have played key roles in increasing the persistence of the insecticidal activity of the Btk formulations, as exemplified in 1997. The greater concentration in a.i. and the greater amount of product used, the more likely the residual insecticidal activity will be retained over a longer period of time, as also concluded by $\mathrm{Li}$ and Fitzpatrick (1996). 
Field trials do not allow to experimentally single out one factor, but they are conveniently suited to address the agronomic and variable meteorological conditions prevailing in commercial settings. The next logical step would be to perform large scale trials in commercial orchards to generate data such that registration of such formulations could be done.

\section{ACKNOWLEDGMENTS}

We thank Benoit Rancourt, Suzanne Fréchette and Han-Su Kim for technical assistance, and Gaétan Bourgeois and his team for access to meteorological data. We thank Bertrand Fournier (SCAD) from Université du Québec à Montréal for advices in statistical analysis. This is contribution no. 335/ 2001.09.01R from the Horticultural Research and Development Centre of Agriculture and Agri-Food Canada at Saint-Jean-sur-Richelieu.

\section{REFERENCES}

Ahmed, S.M., M.V. Nagamma, and S.K. Majumder. 1973. Studies on granular formulations of Bacillus thuringiensis Berliner. Pestic. Sci. 4 : 19-23.

Baker, C.A., A.A. Brooks, R.Z. Greenley, and J.M.S. Hennis. 1987. Encapsulation method. Eur. Patent 0320483.

Bok, S.H., W.L. Hang, K.H. Son, U.K. Sung, W.L. Jee, Y.K. Do, and K.K. Kwon. 1993. Process for preparing coated microbial pesticides and pesticides produces therefrom. U.S. Patent \# 5,273,749.

Burges, H.D., and K.A. Jones. 1998. Introduction. Pages 1-4 in H.D. Burges (ed.), Formulation of Microbial Biopesticides : Beneficial microorganisms, nematodes and seed treatments. Kluwer Academic Publishers, Dordrecht, The Netherlands.

Carrière, Y., J.-P. Deland, D.A. Roff, and C. Vincent. 1994. Life history costs associated with the evolution of insecticide resistance. Proc. Roy. Soc. London B Bio. $258: 35-40$.

Dulmage, H.T., O.P. Boening, C.S. Rehnborg, and G.D. Hansen. 1971. A proposed standardized bioassay for formulations of Bacillus thuringiensis based on the international unit. J. Invertebr. Pathol. 18 : 240-245.
Dunkle, R.L., and B.S. Shasha. 1988. Starchencapsulated Bacillus thuringiensis : a potential new method for increasing environmental stability of entomopathogens. Environ. Entomol. 17 : 120-126.

Dunkle, R.L., and B.S. Shasha. 1989. Response of starch-encapsulated Bacillus thuringiensis containing ultra-violet screens to sunlight. Environ. Entomol. $18: 1035-1041$.

Frye, R.D., C.G. Scholl, E.W. Scholz, and B.R. Funkle. 1973. Effect of weather on a microbial insecticide. J. Invertebr. Pathol. 22 : 50-54.

Hardman, J.M., and S.O. Gaul. 1990. Mixtures of Bacillus thuringiensis and pyrethroids control winter moth (Lepidoptera : Geometridae) in orchards without outbreak of mites. J. Econ. Entomol. 83 : 920-936.

Hostetter, D.L., C.M. Ignoffo, and W.H. Kearby. 1975. Persistence of formulations of Bacillus thuringiensis spores and crystals on eastern red cedar foliage in Missouri. J. Kans. Entomol. Soc. 48 : 189-193.

Jones, K.A., and H.D. Burges. 1998. Product stability : from experimental preparation to commercial reality. Pages 163-171 in H.F. Evans (ed.), Microbial Insecticides: Novelty or Necessity? BCPC Symposium Proceedings no. 68, Surrey, UK.

Li, S.Y., and S.M. Fitzpatrick. 1996. The effects of application rate and spray volume on efficacy of two formulations of Bacillus thuringiensis Berliner var. kurstaki against Choristoneura rosaceana (Harris) (Lepidoptera : Tortricidae) on raspberries. Can. Entomol. 128 : 605-612.

Li, S.Y., S.M. Fitzpatrick, and M.S. Isman. 1995. Susceptibility of different instars of the obliquebanded leafroller (Lepidoptera : Tortricidae) to Bacillus thuringiensis. J. Econ. Entomol. 88 : 610-614.

McGuire, M.R., and B.S. Shasha. 1990. Sprayable self-encapsulating starch formulations for Bacillus thuringiensis. J. Econ. Entomol. 83 : 1813-1817.

Pinnock, D.E., R.J. Brand, and J.E. Milstead. 1971. The field persistence of Bacillus thuringiensis spores. J. Invertebr. Pathol. $18: 405-411$.

Raun, E.S., and R.D. Jackson. 1966. Encapsulation as a technique for formulating microbial and chemical insecticides. J. Econ. Entomol. 59 : 620-622.

Reissig, W.H. 1978. Biology and control of the obliquebanded leafroller on apples. J. Econ. Entomol. 71 : 804-809.

Reissig, W.H., B.H. Stanley, and H.E. Hebding. 1986. Azinphosmethyl resistance and weight-related response of obliquebanded leafroller (Lepidoptera : Tortricidae) larvae to insecticides. J. Econ. Entomol. 79 : 329-333. 
Rigby, S. 1991. Bt in crop protection, p. 51-55. PJB Pub. Ltd, U.K.

Shorey, H.H., and R.L. Hale. 1965. Mass-rearing of the larvae of nine noctuid species on a simple artificial medium. J. Econ. Entomol. 58 : 522-524.

Smirle, M.J., C. Vincent, C. Zurowski, and B. Rancourt. 1998. Azinphosmethyl resistance in the obliquebanded leafroller, Choristoneura rosaceana : reversion in the absence of selection and relationship to detoxication enzyme activity. Pestic. Biochem. Physiol. 61 : 183-189.

van Frankenhuyzen, K., and C.W. Nystrom. 1989. Effect of temperature on mortality and recovery of spruce budworm (Lepidoptera : Tortricidae) exposed to Bacillus thuringiensis Berliner. Can. Entomol. $119: 941-954$.

Zar, J.H. 1996. Biostatistical analysis. 3e ed. Prentice Hall, Upper Saddle River, New Jersey. 662 pp. 